Illinois State University

ISU ReD: Research and eData

Theses and Dissertations

3-28-2018

\title{
The Readers Constructed By Shakespeare Anthologies And Pedagogical Scholarship
}

Andrea Berns

Illinois State University, aberns@ilstu.edu

Follow this and additional works at: https://ir.library.illinoisstate.edu/etd

Part of the Curriculum and Instruction Commons, Educational Methods Commons, and the English Language and Literature Commons

\section{Recommended Citation}

Berns, Andrea, "The Readers Constructed By Shakespeare Anthologies And Pedagogical Scholarship" (2018). Theses and Dissertations. 842.

https://ir.library.illinoisstate.edu/etd/842

This Thesis is brought to you for free and open access by ISU ReD: Research and eData. It has been accepted for inclusion in Theses and Dissertations by an authorized administrator of ISU ReD: Research and eData. For more information, please contact ISUReD@ilstu.edu. 


\title{
THE READERS CONSTRUCTED BY SHAKESPEARE ANTHOLOGIES
}

\section{AND PEDAGOGICAL SCHOLARSHIP}

\author{
Andrea Berns
}

\section{Pages}

In this thesis, I determine that modern Shakespeare anthologies and scholars of Shakespeare pedagogy depict readers with certain learning needs that may not be representative of the "real" readers currently enrolled in undergraduate classrooms. To determine where the "constructed" readers depicted in these two fields overlap and diverge, I will analyze in chapter one the readers constructed in a selection of five Shakespeare anthologies (Bedford, Pearson, Riverside, Norton, and Oxford). I determine that the readers constructed by these anthologies require dynamic features that make the challenge of learning Shakespeare an enjoyable experience. In the second chapter, I analyze the readers of Shakespeare depicted in a selection of pedagogical scholarship (Rex Gibson, Michael Flachmann, Anthony B. Dawson, and Ann Thompson). I determine that the readers constructed by these scholars not only require but have the abilities to learn Shakespeare through performance activities and must be persuaded to approach Shakespeare as a literary text in addition to a script made for performance. I ultimately conclude that the variety of approaches available due to the differences between the readers constructed by two fields may actually be beneficial to "real" readers of Shakespeare. However, if the two constructed readers are not accurately representative of "real" readers, these "real" readers may not be receiving the tools they need to effectively study a Shakespeare text.

KEYWORDS: Shakespeare; Early modern literature; Modern anthologies; Constructed readers; Pedagogical scholarship 
THE READERS CONSTRUCTED BY SHAKESPEARE ANTHOLOGIES AND PEDAGOGICAL SCHOLARSHIP

ANDREA BERNS

A Thesis Submitted in Partial

Fulfillment of the Requirements

for the Degree of

MASTER OF ARTS

Department of English

ILLINOIS STATE UNIVERSITY 
(C) 2018 Andrea Berns 
THE READERS CONSTRUCTED BY SHAKESPEARE ANTHOLOGIES AND PEDAGOGICAL SCHOLARSHIP

ANDREA BERNS

COMMITTEE MEMBERS:

Tara Lyons, Chair

Katherine Ellison 


\section{ACKNOWLEDGMENTS}

I would like to thank my thesis advisor, Dr. Tara Lyons of the English department at Illinois State University for her honest feedback, helpful encouragement, and constant availability to assist me with any questions I may have encountered while writing this thesis. Whenever I felt my confidence in my work fading, she was always available to talk through my ideas and build it back up.

I would also like to thank Dr. Katherine Ellison, also of the English department at Illinois State University for serving as my second reader. Dr. Ellison's detailed feedback added several layers of depth into my research that wouldn't have been possible without her insight. I am so thankful for her contribution to my thesis.

Finally, I would like to acknowledge my gratitude to my parents for their constant support throughout this arduous but rewarding writing process, and to my friends Joseph, Chloe, and Cody for reading my thesis and providing me with feedback and support.

A.K.B. 


\section{CONTENTS}

Page

ACKNOWLEDGMENTS

CONTENTS

CHAPTER I: INTRODUCTION 1

Why Study the Constructed Reader? $\quad 4$

$\begin{array}{ll}\text { Chapter Breakdown } & 9\end{array}$

CHAPTER II: THE READERS CONSTRUCTED BY SHAKESPEARE ANTHOLOGIES 11

The Bedford Shakespeare (2015) 12

Pearson's The Complete Works of Shakespeare (2014) 17

The Riverside Shakespeare (1997) 22

The Norton Shakespeare (2016) 28

The New Oxford Shakespeare: Modern Critical Edition (2016) 31

Analyzing the Readers Depicted in Shakespeare Anthologies 35

CHAPTER III: THE READERS CONSTRUCTED BY SHAKESPEARE PEDAGOGY 40

$\begin{array}{ll}\text { Performance-Based Shakespeare } & 40\end{array}$

Literary Critical Shakespeare $\quad 45$

Analyzing the Readers Depicted in Pedagogical Scholarship 50

Comparing the Readers Constructed in Anthologies and Pedagogical Scholarship 52

$\begin{array}{ll}\text { Conclusion } & 60\end{array}$

$\begin{array}{ll}\text { REFERENCES } & 64\end{array}$ 


\section{CHAPTER ONE: INTRODUCTION}

When the editors and publishers of Shakespeare's complete works produce a printed anthology for modern readers, these books are often designed to be used in university Shakespeare courses. The producers of these anthologies frequently imagine readers to have certain qualities, interests, and learning styles. These anthologies are often then designed specifically for these imagined readers, although it is unclear how well these constructed readers represent the actual qualities, interests, and learning styles of student readers in university Shakespeare courses. In most cases, the mediator between the anthology's content and these readers is the person who assigns the textbook to the class: the university instructor. Unlike the producers of the anthology, the instructor has more direct contact with the readers of the anthology and on a regular basis in the classroom. In pedagogical scholarship that explores the best ways to teach students to read Shakespeare, these instructors present their own understandings of the qualities, interests, and learning styles of their student readers. Therefore, similar to the anthologies, scholars also construct a reader in their pedagogical scholarship. Some qualities of the constructed reader of the anthology may overlap with the constructed reader of pedagogical scholarship, but there certainly may also be divergences. This thesis will analyze these discrepancies as well as points of commonality among a selection of five anthologies and a range of Shakespeare pedagogical scholarship. My thesis ultimately asserts that the variety of approaches made available due to the divergences between the readers constructed by the anthologies and in pedagogy could be beneficial for students of Shakespeare currently in university classrooms. However, if the readers constructed in the anthologies and in pedagogical scholarship are not accurately representative of the diverse demographics and learning needs of the readers in current university classrooms, these "real" readers may not be receiving the tools they need to effectively study Shakespeare's works. 
To examine the readers constructed in Shakespeare anthologies, I have selected five different editions of Shakespeare's complete works: The Riverside Shakespeare (1997), The Complete Works of Shakespeare published by Pearson Education (2014), The Bedford Shakespeare (2015), The Norton Shakespeare (2016), and the Modern Critical Edition of The New Oxford Shakespeare: The Complete Works (2016). From here on, these anthologies will be referred to as the Riverside, the Pearson, the Bedford, the Norton, and the Oxford. My reasoning for selecting these particular anthologies is to have an array of Shakespeare's complete works that are all from highly-regarded academic publishers but are different in their approaches to the content. In my analysis, I will examine the language and layout of what Gerard Genette refers to as the "paratext" of the anthology, or the material provided by the editors or publishers that "surround" and "extend" the text "in order to present it" (Genette 1). In each anthology, the paratextual elements include the prefatory material, general introduction or other textual apparatus, images, essays, and annotations, which I will analyze to determine and describe the qualities of the constructed reader each anthology depicts. More specifically, I will focus on the representation of the text of King Lear in each anthology.

My selection of this particular play is due to its variable presentation across the five anthologies. The play has two significantly different versions of the earliest text, printed fifteen years apart: The First Quarto in 1608 and the First Folio in 1623. The Folio omits approximately 285 lines found in the Quarto and has an addition of approximately 115 lines that are not found in its predecessor (Blayney 1). In addition, dialogue is assigned to other characters, stage directions are re-placed or omitted, and differences in wording could subtly but significantly change the meaning. It has been interesting to see how this topic is handled among the anthologies: whether editors provide annotations of textual variants, the extent to which they 
devote the space in their textual apparatuses to introducing early modern dramatic publishing to the reader, or whether they provide alternate versions of selected scenes or even the two versions of the play in their entirety. All of these factors can help us understand what kinds of readers the producers of these anthologies are targeting and what qualities they imagine their readers having.

To analyze the reader of Shakespeare depicted in published pedagogical scholarship, I have chosen research that examines different approaches to teaching Shakespeare in the undergraduate classroom. While I will mainly be analyzing scholarship on the teaching of undergraduate students, research by pedagogy scholars such as Rex Gibson can also be applied to high school students, as Gibson discusses readers of Shakespeare of all ages below postgraduate study in his work. The pedagogical scholarship I will be analyzing can be divided into two categories: those that advocate teaching Shakespeare's plays as a script created to be performed and those that encourage teaching his plays as literary texts, using critical theory such as structuralist, new historicist, cultural materialist, and feminist methods to read and analyze the plays. In other words, some pedagogy scholars, such as Gibson and Michael Flachmann, find it beneficial for students to approach the play as an actor would, with in-class performance activities such as reenacting scenes in modern-day contexts and roleplaying dialogue while emotionally connecting with dramatic situations as an actor would to prepare for a role. Others, such as Anthony B. Dawson and Ann Thompson, believe performance activities should be accompanied by a more scholarly method, using close-reading, studying the historical context, and using critical theories to analyze the plays. Performance and literary approaches are used in different contexts and for different purposes, but pedagogy scholars suggest that both are needed in the classroom for a well-rounded education in Shakespearean literature. Whether the readers 
depicted in the pedagogy research are accurate representations of "real" readers of Shakespeare, however, is debatable. The reasoning for this is covered in the next section.

\section{Why Study the Constructed Reader?}

My approach to examining the readers who are constructed in Shakespeare anthologies and pedagogical scholarship is informed by reader response theory, or "aesthetic response," as introduced in Wolfgang Iser's 1978 book, The Act of Reading. According to Iser, aesthetic response is the relationship and interaction between the two poles of a literary work: the artistic — i.e. the author's text—and the aesthetic — i.e. the reader's realization of the text (Iser 21). Iser conveys how the concept of the "reader" is not a monolithic entity but instead comprised of many types of readers who are invoked when a literary critic makes a statement about the effects or responses to literature, described in two categories: the "hypothetical" reader and the "real" reader.

The "hypothetical reader" is all possible realizations that may be evoked, which is not easily generalized (Iser 27). The five anthologies I will be analyzing have each been edited, and the paratexts have been written, with certain expectations that the reader will respond in certain ways, a role that Iser titled the "ideal reader," who Robert Dale Parker explains is constructed to "respon[d] to challenges and mysteries in the text "with relish" (Parker 280). Parker continues:

As we read a text, we can sort out implicit assumptions that it makes about its readers, what they know and believe or do not know and believe. But a text always remains incomplete, all the more obviously while readers find themselves in the middle of its sequence of words and implications. In that way, a text sets up "gaps," inviting readers to fill in the gaps and inviting 
readers then to compare how they fill in the gaps to the way that the text itself eventually fills or does not fill in the same gaps (Parker 280-281)

These gaps in the text may or may not be filled by the actual readers due to their specific learning needs and interests that the text may or may not fulfill. Some readers may not respond to the challenges and mysteries in the manner that the text expects them to and, therefore, the implicit assumptions about the reader are in many cases inaccurate. This is proven in Iser's statement that the ideal reader is "a structural impossibility" because one would need to have "an identical code to that of the author" and "share the intentions underlying this process" (Iser 29). The ideal reader is, therefore, "a purely fictional being" who can "close the gaps that constantly appear in any analysis of literary effects and responses" and "can be endowed with a variety of qualities in accordance with whatever problem he is called upon to help solve" (Iser 29). The only ideal reader who could possibly exist, Iser claims, is the author themself (Iser 29). Iser's approach to readers can help us understand how the creators of each Shakespeare anthology added specific features, wrote specific paratexts, and provided specific annotations with the expectations that readers would respond the way the creators themselves would.

The phrase "real reader" implies that the documented reactions of readers are accurate, but Iser argues that these documented reactions cannot exist objectively (Iser 27). For example, they may "simply represen[t] the role which the author intended the reader to assume" (Iser 28). In other words, the written statement that a text evokes certain reactions in readers may have been influenced by the intended reaction that the researcher hoped readers would assume. Another reason is the influence of bias based on the limitations of the sample of readers who are not necessarily representative of the wide range of demographics that make up the readers of Shakespeare. An example of this appears in an essay by Dartmouth College professor Dr. Lynda 
E. Boose, a contributing author to Robert H. Ray's edited collection of essays, Approaches to Teaching Shakespeare's King Lear (1986). Boose describes the demographics of the students in her opening paragraph about how her class reads King Lear:

In preparing to teach the play, one cannot avoid being conscious of the unbridgeable gap between our students' experience of life and the enormous age and pain of the irascible old king who is himself responsible for most of the suffering and for whom there is no time left in which to make amends, begin again, or redeem the past—no opportunity, in other words, to do any of those things that our students' youth, their middleclass affluence, and the optimistic premises of their American culture assume to be inalienable rights (Boose 59).

Boose's depiction of undergraduate students of Shakespeare as young, belonging to the middle class, and a product of American culture is not representative of students of Shakespeare who do not meet these demographics: nontraditional students, those who come from low-income families, and those born in a country outside of the United States, including international students in U.S. universities. Keith F. Punch further explains in his 2009 book, Introduction to Research Methods in Education the potential bias and subjectivity that arises when instructors conduct research in their own classroom:

The very nature of the teacher-researcher's insider position may bring the risk of subjectivity and bias. It may be difficult, in other words, to maintain a dispassionate, objective, arm's length approach to the research situation. Selective sampling, bias in the collection or analysis of the data, 
and bias in the interpretation of results are obvious possibilities (Punch 44).

The possibility of bias, therefore, leaves one aware of the challenges of interpreting the readers described in pedagogical scholarships as the "real" readers. It is for this reason that I will approach the reader of Shakespeare depicted in pedagogy research as an imaginary reader constructed by the researcher as opposed to the actual student of Shakespeare. My approach further illustrates the various dimensions of the reader as depicted in Iser's aesthetic response theory, as opposed to approaching the reader as a monolithic entity.

In addition to reader response theory, my analysis of the five Shakespeare anthologies is informed by the theories of textual studies and editorial theory. In the introduction to Textual Editing and Criticism, Erick Kelemen defines textual criticism as "the practice of identifying and correcting — emending — errors in the text" to "identify for readers points of ambiguity or disagreement about a text" (Kelemen 5). A significant aspect of textual criticism is in terms of the "history of a text, from its composition to the most current editions" (5). The textual history includes the editorial decisions made by editors of the text, in which "even small differences...can be significant" and "shap[e] different meanings as we read" (6).

In this thesis, I hope to contribute to the conversation already brewing between scholars who have approached similar topics through the lens of this theory. For example, in Shakespeare's Modern Collaborators (2008), Lukas Erne ${ }^{1}$ discusses the important decisions an editor must make when preparing a Shakespeare text for readers, such as "how to emend" as well as "whether to emend" (Erne 22). Erne makes it clear that whether or not an editor chooses to emend the text in a certain way is just as important as the manner in which the editor emends the

\footnotetext{
${ }^{1}$ Other scholars who wrote on similar topics include Jowett 115-35, Kidnie 456-473, Tanselle 1-56, and Walker 95105.
} 
text, as all decisions may either assist the modern reader or cause confusion for them. Erne provides examples of editorial choices, such as deciding on an abbreviated speech prefix each time a character speaks. Abbreviated prefixes such as 'Rom.' and 'Jul.' may be clear in Romeo and Juliet, but prefixes such as 'Var. Serv.', 'Caph.', and 'Jew.' in Timon of Athens may cause confusion for those who may not recognize the abbreviated forms of the characters' names (Erne 39). Another example of an editorial choice that may affect the modern reader is whether to format a character's dialogue as prose or verse, which ultimately conveys the manner in which a character is perceived. Erne gives an example of the dialogue of the Nurse in Romeo and Juliet: if the editor wishes to convey her as a "mere wet-nurse" for comic purposes, prose would be more appropriate, but if the editor wishes to distinguish her an agent involved in "the play's tragic intrigue," the editor may consider verse (Erne 30-31). Upon considering all these elements that make up the crucial decisions an editor must make, I wish to approach this subject in the sense of determining the reader for whom editors imagine making these decisions and what editors hope readers will gain from their decisions. I then take it a step further by providing the perspective of the instructors and how they perceive the learning needs of readers of Shakespeare. However, because the readers depicted in Shakespeare anthologies and in scholarship are constructed by varying factors that are interpreted by different individuals, there will inevitably be divergences in the perceived qualities and learning needs among the depicted readers. These divergences ultimately result in consequences that could either be beneficial or problematic for current undergraduate readers of Shakespeare.

A significant factor in my study of the texts in the five Shakespeare anthologies is the paratext, of which I previously quoted a definition by Gerard Genette. The paratext of an anthology is significant, as it is the "threshold," "vestibule," or "zone" between "text and off- 
text" that serves as "a better reception for the text and a more pertinent reading of it" and is ultimately "what enables a text to become a book and to be offered as such to its readers and, more generally, to the public" (Genette 2). In his book, Editing Early Modern Texts (2009), Michael Hunter refers to the paratext of an anthology of early modern works as the "textual apparatus," which he claims is "where editors are at their most important" (Hunter 92). It is present to assist the reader by "codifying and encapsulating" the editor's research "to make sense of the text at both a general and specific level" (Hunter 92). In other words, the textual apparatus, or paratext, surrounding the plays themselves contains crucial information that embodies the editor's research and is made accessible for the reader's reference as they study the text. Without the paratext, the reader is only left with Shakespeare's text itself, which in many cases would be alienating and daunting to readers who require additional material in order to engage with Shakespeare's text. Therefore, each Shakespeare anthology provides a paratext that the editors and publishers believe will best assist the readers they imagine as the consumers of the edition. Therefore, through the lens of textual studies, I will analyze the paratextual material of each anthology and, through the lens of editorial theory, analyze the reasoning of the anthology's creators for providing this material and, if a revised edition, their reasoning for adding or revising the anthology from previous incarnations. From these analyses, I will then draw from reception theory to examine the kinds of readers each anthology constructs.

\section{Chapter Breakdown}

This thesis is comprised of two chapters. Chapter one analyzes each of the five anthologies in this order: Bedford, Pearson, Riverside, Norton, and Oxford. For each anthology, I will describe the content and appearance of the anthology and examine the qualities of the reader the anthology appears to target. In this chapter, I conclude that the readers constructed by these 
five Shakespeare anthologies require dynamic features that make the challenge of learning Shakespeare an enjoyable experience. Chapter two describes the learning needs of the reader of Shakespeare as depicted by four pedagogy scholars: Rex Gibson, Michael Flachmann, Anthony B. Dawson, and Ann Thompson. I conclude that the reader of Shakespeare depicted in pedagogical scholarship requires a balance of approaching Shakespeare's plays as a performance and as a literary text. The chapter will ultimately conclude with an analysis of the similarities and differences between the constructed readers in anthologies and pedagogical scholarship. I conclude the thesis by arguing that the differences in how the anthologies and scholarship approach the reader of Shakespeare could actually be beneficial for current students in undergraduate classrooms due to the variety of approaches to reading Shakespeare's texts that are made available, but if the constructed readers are not representative of "real" readers of Shakespeare, these readers may not be receiving the tools they need to effectively study a Shakespeare text. 


\section{CHAPTER TWO: THE READERS CONSTRUCTED BY SHAKESPEARE ANTHOLOGIES}

Upon analyzing the paratexts of the five Shakespeare anthologies and how editors present the text of King Lear, it becomes clear that the anthologies construct different readers of Shakespeare, but patterns do emerge among the anthologies. It is these patterns that this chapter

will examine closely. Each edition provides paratextual material to inspire or assist students with engaging with the text, but the editions diverge in the ways this paratextual material is shaped based on the kinds of readers the editors are imagining. In this chapter, I argue that the Bedford and Pearson anthologies construct a reader who requires knowledge of Shakespeare's relevancy to them in order to engage with the plays, the Riverside constructs a reader who has a preexisting grasp of the fundamentals of Shakespeare as well as admiration for Shakespeare as a significant historical writer, the Norton constructs a reader who requires analysis of textual variants across several versions of the same play to engage with Shakespeare, and the Oxford constructs a reader who requires engaging with Shakespeare similar to the way one would view a performance on stage. My analysis of the constructed readers across each of the five anthologies ultimately demonstrates that while some of the goals of the editors are the same, the manners in which they carry out their goals in their editing of the anthology are very different and, therefore, lead to different target audiences. Depicting the readers constructed in this sample of anthologies will allow us to see what editors are providing undergraduate readers so we may then compare it to how scholars of Shakespeare pedagogy depict the learning needs of undergraduate readers in the next chapter. 


\section{The Bedford Shakespeare (2015)}

The Bedford anthology appears to construct a reader who requires an understanding of the fundamentals of Shakespeare, such as interpreting the language and imagining the scene coming to life. The editors, Goldsmiths College at the University of London professor Russ McDonald and Georgetown University professor Lena Cowen Orlin, appear to believe that these learning needs are based on a lack of interest in Shakespeare due to the belief that Shakespeare is not relevant to them as readers in the twenty-first century. This is evidenced by the prefatory material, which states how editors McDonald and Orlin conceived the needs of their readers, and by the editorial decisions they subsequently made. While conducting research for the 2015 anthology, the editors surveyed several hundred students and their instructors about the challenges they encounter in a Shakespeare classroom. Responses ranged from difficulties with Shakespeare's language and imagining the performance of a scene as well as requiring more information about early modern history (Bedford ix). No demographical statistics or other data on this study is provided, which makes it impossible for others to evaluate the study's methods and results, especially in respect to the demographics of the teachers and students in the study. The Bedford accommodates the needs of this particular sample of students through the format and features of the anthology. Unlike other anthologies, in which the paratextual material is compiled into a general introduction at the beginning of the anthology and into the critical introductions before each play, the Bedford replaces the general introduction with labeled sections of information interspersed throughout the anthology. For example, inserted between each play is a section labeled "Context," which briefly introduces topics that provide important background information and a deeper understanding of early modern history and its culture (Bedford xi). Several of these topics include "Language" (605-609), "Nature" (880-885), 
"Race," (1098-1103), and "Society" (1396-1401). The anthology also provides three essays, “Approaching Shakespeare" (1-5), "Screening Shakespeare" (1326-1329), and "Staging Shakespeare" (1546-1549) to provide support and insight on "intelligent and imaginative engagement" in understanding the plays as a performance (Bedford vii and xii). In lieu of a critical introduction to each play, the Bedford provides multiple sections of paratext interspersed throughout the anthology. This includes a brief "Preview" before each play, which McDonald and Orlin claim provides readers with information they need to know in order to "enter the world of the play" (Bedford ix). An in-depth critical analysis labeled "View" follows each play. "Asides"—or "pop-up materials"-are interspersed throughout each play to provide close readings and scholarly or theatrical interpretations of key passages, as well as historical or contextual information. "Afterlife" sections provide an illustrated timeline of publications and productions, both theatrical and film, of each respective play. The "Action" section preceding each play provides brief scene-by-scene summaries of each play. In addition, editors McDonald and Orlin provide concise glosses, offering "the most immediately helpful information" while saving more in-depth explanations for the Asides. (Bedford vii and xii). McDonald and Orlin market these snippets of paratext as "digestible" and "compact" (Bedford xi), which suggests that the constructed reader prefers to absorb short bursts of information at a time in order to retain and process information more easily.

In addition to preferring small bursts of information at a time, the Bedford's constructed reader also appears to require "visual" and "dynamic" (Bedford ix) features throughout the anthology in order to capture and maintain their attention throughout the entire reading process. The provided features reflect Orlin's scholarship that specializes in the social, economic, and architectural history of early modern culture. These features include images of early modern 
woodcuts, maps, or stills of the respective play in performance. These are designed to "inform" and "stimulate" readers as well as "provide opportunities for class discussion" (Bedford ix). Browsing through the edition, these features that adorn the majority of pages in the anthology along with plenty of whitespace make for a visually-appealing layout that appears to be for the purpose of capturing and maintaining the reader's interest throughout the reading process so that there is always an image to admire or a tidbit of information to explore.

Along with the visually dynamic features in the anthology, the content of the paratext appears to be for the purpose of informing their readers how Shakespeare is relevant to twentyfirst century lives and that his plays feature characters and dramatic situations that are identifiable to readers across centuries. In the Preview of King Lear that precedes the play, Russ McDonald uses language that humanizes characters in the play, beginning the section with the following:

Meet King Lear and his daughters, an especially dangerous version of the dysfunctional family. King Lear contains some of the most poisonous human interactions ever represented in fiction, and because these relationships are familial, readers and audiences have found extraordinary resonance in this dark drama. (Bedford 1332)

These sentences not only appear to introduce readers to the dynamic relationships on which the play focuses but also paint a picture of how past readers have found resonance with the humanity represented in the play. Acknowledging this human connection appears to encourage undergraduate readers to also seek resonance with the play and identify with characters and the situations in which they find themselves. To assist readers with this, McDonald uses his specialization in Shakespeare's poetic language to 
provide a response to a simile uttered by the Earl of Gloucester in act four: "As flies to wanton boys are we to th'gods; / They kill us for their sport" (4.1.36-37). McDonald responds:

This negative reading acknowledges the brutality suffered by the characters and the apparent lack of any supernatural consolation or retribution - in short, the absence of justice. There is more to the play than such nihilism, and yet its darkness seems practically inescapable. (Bedford 1332)

Here, McDonald reveals the scope of the play's theme, providing the reader with a humanizing description that details why readers and audiences have responded throughout history the way they have. This is evident in McDonald's use of words that evoke human experiences such as "brutality," "suffer," “absence of justice” and "inescapable darkness.” McDonald and Orlin appear to believe that if their constructed readers are able to identify with the characters, they will be met with clarity and successfully engage with the play. For example, McDonald shapes the character of Lear for the reader in the following paragraph:

King Lear is a tragedy, and King Lear is its tragic protagonist, but our response to him and his experience is affected by political and cultural shifts of the last four centuries. The irrational old king hardly behaves like a tragic figure initially; on the contrary, his manner seems erratic and unheroic, the predictable sputterings and self-absorption of an aged autocrat. By the middle of the play, as his first two daughters abuse him openly, we generally feel pity and sympathy but cannot deny that the unstable monarch has done much to bring about such pain. (Bedford 1332) 
Using words such as "irrational," "old," "erratic," "unheroic," and "self-absorption" paints the character of Lear for the reader with specific adjectives for the apparent purpose of giving readers the tools to imagine the character with help from an image of a haggard Henry Irving from the 1892 production in London on the following page. This appears to be for the purpose of evoking in the reader connections to a person the reader knows in their life, or a character they saw in a film or previously read in a book. McDonald's statement about generally feeling pity once again appears to be for the purpose of evoking the reader's emotions, this time a cognitive dissonance of feeling pity for a person who yet has brought about pain to other characters, a seemingly familiar emotion of the human experience.

McDonald's conjuring of the reader's empathy while emphasizing Shakespeare's depiction of humanity also appears to be an attempt to convince readers of Shakespeare's relevance in contemporary society. In his paratexts, McDonald brings to life the "savagery" and "inhumanity" of King Lear that is "unmatched in any Shakespeare play except perhaps Titus Andronicus." McDonald recalls the scene in which Gloucester's eyes are gouged out as "one of the cruelest scenes in world drama" (Bedford 1332), a statement that brings to light the significance of Shakespeare's writing throughout human history. This seems to be for the purpose of providing students with the tools to understand how Shakespeare's writing continues to be relevant centuries later. McDonald's following statement explores Shakespeare's relevance further:

In King Lear, Shakespeare confronts the extremes of human behavior, so the merciless actions of the wicked children, along with those of the psychotics and toadies surrounding them, represent the negative side of a moral and ethical spectrum. Their brutality is balanced by the selfless 
actions of Lear's daughter Cordelia, Gloucester's son Edgar, the Earl of Kent, the Fool, and a few others (Bedford 1332).

Here, McDonald simultaneously conveys the themes of the play while illustrating Shakespeare's relevance as a writer in his portrayal of the human condition. Shakespeare captures the dichotomy between good and evil in this particular play, which McDonald claims "emphasize[s] the symbolic, universal quality of the work" (Bedford 1333). McDonald's use of the word "universal" to describe Shakespeare's play appears to imply that Shakespeare's writing is relevant to all humans in every generation.

All the above features of the Bedford construct a specific type of reader: one who learns best and finds interest in Shakespeare because his writing is relevant to them in the twenty-first century. The Bedford thus provides visually appealing images along with short segments of paratext to maintain the reader's interest. The anthology also uses specific language to evoke the reader's emotions to show how Shakespeare is relevant to them as readers in the twenty-first century.

\section{Pearson's The Complete Works of Shakespeare (2014)}

Whereas the Bedford constructs a reader who requires dynamic paratextual material in short segments in order to maintain interest and imagine the scenes come to life, the Pearson appears to construct a reader who prefers the entirety of the information compiled into a general introduction detailing the historical background and cultural context surrounding Shakespeare's plays to conjure a visual image of the culture, attire, and scenery during Shakespeare's time period. Additionally, the reader constructed by the Pearson aligns with that of the Bedford's in the sense that both readers must be convinced that Shakespeare is relevant to twenty-first century audiences through the paratext's language that describes the characters and scenarios in a 
humanizing fashion. However, the Pearson adds a more theatrical element to this relevancy, appearing to suggest that readers must view a performance of the play in a film or on stage to fully engage with the play.

The constructed reader of the Pearson anthology, like the Bedford, requires visual features to imagine the scene taking place, but both anthologies accommodate this learning need in different ways - the Pearson through a lengthy general introduction and the Bedford through short segments of information at a time. This is evidenced by the 91-page general introduction illustrated in black and white, offering readers the historical background and cultural context surrounding Shakespeare's plays. This suggests that the Pearson assumes the anthology will be useful to a reader who, unlike the Bedford's reader (2015), can maintain interest for long periods of time while reading a lengthy introduction. Unlike the Bedford, which features images interspersed throughout the anthology, all images in the Pearson are placed in the general introduction, thus readers will need to refer back to them to visually immerse themselves in the culture of Shakespeare's time period. Visual features in the general introduction include "Shakespeare's World: A Visual Portfolio," which includes 16 pages of full-color images of paintings, maps, and film and theatrical performances of various plays, which editor David Bevington, a professor at the University of Chicago, states is "to help readers visualize Renaissance life and culture and to trace the history of significant performances on stage and screen" (Pearson vi). One full-color illustration in the Pearson features three images depicting Elizabethan attire according to social class: a "workman" with tools, a "presumptuous woman" implied to not be worthy of her extravagant clothes, and a "gentleman" who appears to have earned the privilege of wearing his noble hat, cape, and collared tunic (7). These illustrations appear to be for the purpose of providing their constructed reader with a visual representation of 
the probable attire of Shakespeare's characters. The panoramic painting of the city of London in Shakespeare's time period also appears to provide readers with a visual idea of the appearance of the streets and buildings during the time period in which the plays take place (1-2). Therefore, the constructed reader benefits from a more visually concrete image to bear in mind as they imagine characters and scenery.

The Pearson also appears to construct readers who need to be convinced that Shakespeare is relevant to them in the twenty-first century. Like the Bedford, the Pearson accommodates this need by evoking emotion through identification, as demonstrated in comments such as, "We identify with Cordelia and Edgar as virtuous children whose worth is misjudged" and "Like any parent, [Lear] wishes to be loved and appreciated" (Pearson 1203). The Pearson appears to give their readers the tools to make personal connections with any characters in whom they may see a part of themselves for the apparent hope for a better understanding of the play and ultimately a deeper appreciation. Another example is the provision of the essay, "Reading Shakespeare in the Twenty-First Century" (Pearson ix), which opens with the question: "Why read Shakespeare today?" Here, the Pearson, like the Bedford, connects with the reader's emotions as he explains Shakespeare's relevance due to his portrayal of the human experience. The Pearson gives concrete examples from Shakespeare's plays, such as characters falling in love, challenging a parental figure's authority, and growing older to lose religious faith and experience middle age (Pearson xi). The Pearson's use of specific examples appears to provide its constructed reader with the tools to identify with Shakespeare's characters. However, where the Pearson truly makes this connection is here:

One beautiful thing about this richly complex portrait of human striving is that it paints a chronological portrait of the life of the human being from 
childhood to middle years and then to a decline toward death, all of this brilliantly laid out by Shakespeare as his plays and poems move from early to late. The plays and poems are the biography of what it is to be human. (Pearson xi)

The Pearson's exploration of Shakespeare's depiction of the human experience appears to offer an insight that the constructed reader needs to understand the universality of Shakespeare's text. The language appears to assume that the readers may not have ever believed that Shakespeare's works could be relevant to their lives in the twenty-first century because of the four-hundredyear barrier. But the Pearson paints a portrait of the ways in which Shakespeare is still relevant to these readers due to the common experiences of humanity. It appears that the Pearson strives readers to make this revelation and, therefore, help the reader find an unprecedented appreciation for Shakespeare's works.

The six-page critical introduction to the text of King Lear continues the conversation on Shakespeare's exploration of the human experience and its effect on audiences throughout history. The Pearson compares the intensity between several of Shakespeare's works in his statements: "Few plays other than Hamlet and Macbeth approach King Lear in evoking the wretchedness of human existence, and even they cannot match the devastating spectacle of the Earl of Gloucester blinded or Cordelia dead in Lear's arms" and "In no other Shakespearean play does injustice appear to triumph so ferociously, for so long, and with such impunity" (Pearson 1201). The Pearson's assessment appears to not only provide readers with connections across Shakespeare's plays in terms of comparable measurement of effect but also provides readers with insight on Shakespeare's skillful achievement of depicting humanity so effectively in multiple works. 
The inclusion of several features in the Pearson, such as the essay "Shakespeare In Performance" (A-50-59), which details the historical approaches to Shakespeare's plays, and the appendix, "Films and Videos as a Guide to the Study of Shakespeare" (A-60-70), a list of filmography based on Shakespeare's plays, appear to be based on Bevington's suggestion that students can become engaged with Shakespeare's plays by viewing theatrical or film adaptations of the plays. It is here where the influence of Bevington's specialization in Theatre and Performance becomes clear, beginning with Bevington's counterargument to the following statement in the essay, "Reading Shakespeare in the Twenty-First Century":

Until recently, Shakespeare was more a required subject in schools and colleges than is the case today. As a mandatory subject, he was resisted like any inflexible requirement. Why study something simply because it is a traditional part of the curriculum? Isn't that boring? In an age when we are inclined to be wary of dead European white male authors, isn't Shakespeare a prime candidate for dismissal? He is all of those things: dead, European, white, and male. (ix)

Bevington's counterargument is that "Shakespeare lives, despite these hazards, in the theater" and "in film and video" (ix). Bevington further states that "The evidence is all around us" because "Shakespeare has enjoyed a remarkable revival in film and video" (ix). Additionally, in his essay, "Films and Videos as a Guide to the Study of Shakespeare," Bevington states: "Watching a production can be fun and exciting. It erases much of the distance of time between Shakespeare's day and our own" (A-60). Therefore, Bevington appears to suggest that once readers view a Shakespearean play in a film or on a stage, they will become more engaged with the play because Shakespeare's 
time period appears to be more relevant with ours. Therefore, while the Bedford's

paratextual material to assist readers with engaging with the text is all in the anthology, the Pearson's paratext extends outside of the anthology to the array of theatre and film adaptations available throughout history.

As the previous analysis demonstrates, while both the Pearson and Bedford anthologies assist readers with engaging interest in Shakespeare's plays, the Bedford's reader appears to require images and short segments of information interspersed throughout the text to maintain interest while the Pearson's targeted reader appears to prefer a compiled general introduction containing information and images that assist them with imagining the time period and a selection of scenes being performed. Additionally, both the Bedford and the Pearson create their respective paratexts to assist readers with engaging with Shakespeare, and both appear to convince their readers that Shakespeare is relevant to them in the twenty-first century. However, the Pearson's readers must explore beyond the anthology and supplement theatrical and film adaptations of Shakespeare's plays in order to fully engage with Shakespeare's text.

\section{The Riverside Shakespeare (1997)}

Upon reviewing the features in the second edition of the Riverside, it appears that the second edition of the Riverside constructs a reader who is very different from those of the Pearson and Bedford. A first glance through the anthology reveals several essays entitled "Twentieth-Century Shakespeare Criticism," "Shakespeare's Text," "Shakespeare's Plays in Performance: From 1660 to 1971," and “Shakespeare's Plays in Performance: From 1970.” Also included are eight pages of full-color illustrations depicting photographs and Elizabethan paintings, an additional eight pages of full-color photos from a selection of film and theatrical productions of Shakespeare's plays, a chronological timeline of Shakespeare's publications, and 
nineteen pages of black-and-white images scanned from Shakespeare's First Folio. Skimming through the prefatory material, Harvard University professor G. Blakemore Evans and University of Massachusetts, Boston professor J.J. M. Tobin note the "sea of change" in critical approaches that occurred since the publication of the first edition in 1974, including new approaches focusing more on sociological, political, and gender-oriented values (Riverside vii). Whereas the previous anthologies provide their respective material as tools to assist their readers with engaging with foundational elements of Shakespeare's text, such as Shakespeare's language and character identification, the Riverside appears to construct a reader who has studied Shakespeare enough to already have a strong grasp of this foundational knowledge to fully appreciate Shakespeare as a writer and historically significant figure. The anthology, therefore, appears to be a source for stimulating ideas to add to a conversation that is already brewing within the mind of the reader, suggesting different approaches to Shakespeare and details about the author's craft of language that the reader can incorporate in their own work. Whereas the Bedford and the Pearson approach Shakespeare's language and the historical context within the paratext and images as tools to assist the reader with understanding the text and convincing them of Shakespeare's relevancy to twenty-first century readers, the Riverside approaches these same topics as if in homage to Shakespeare's legacy as a historically significant playwright.

The respect for Shakespeare as a historically significant writer can be seen in the section labeled "Historical Background" in the general introduction, which begins with the following sentence:

We can follow the development of Shakespeare's work in greater clarity if we view it as a response to, and an expression of, the proud and eventful 
period in which he lived and for which he constructed the principal monument. (Riverside 5)

The words "proud" and "eventful" that Levin uses suggests a romanticized, nearly regal connotation associated with the time period in which Shakespeare graced the earth with his existence. This is even further demonstrated in Levin's acknowledgement that the year of Shakespeare's birth marked the deaths of Michelangelo and Calvin, which "set[s] him at the zenith of the two great formative movements in the arts and religion that they personify, the Renaissance and the Reformation" (Riverside 5). Describing the time period as a "zenith" further demonstrates Levin's seemingly apparent bardolatry to an extent that even the editors of the Bedford (2015 and Pearson anthologies fall short. However, whereas the Bedford and Pearson anthologies seem to be attempting to plant a new appreciation for Shakespeare in their constructed reader, the Riverside appears to expect their readers to already have a reverence for the author and his works.

A section in the general introduction labeled "The Linguistic Medium" further illustrates how the Riverside assumes the reader already appreciates Shakespeare's genius. While the Bedford and Pearson editions acknowledge the difficulty of the language barrier between Shakespeare and contemporary society, the former anthology even providing analyses of key passages throughout the plays, the Riverside approaches this language barrier as a "demanding" and "rewarding task of elucidation" (Riverside 9). Levin approaches Shakespeare's language as an enjoyable experience similar to cracking a code and implies that their reader finds the same pleasure in it. Levin glorifies Shakespeare's use of language through logic, grammar, and rhetoric as the "art of persuasion by words," calling his characters "dialecticians," and praising his vast vocabulary of over 21,000 words: "probably a wider range than any other writer" 
(Riverside 9). Levin further praises Shakespeare's word choice, stating he was "more than a master at putting the proper word in the proper place" and could even "inspire some of his slower-witted characters with a gift for putting the improper word in the proper place" (Riverside 11). In terms of characterization, Levin calls Shakespeare's skill "dynamic" to the extent that, by the late eighteenth century, it was seen as "an act of creation." Critics from the nineteenth century treated the characters of Shakespeare "as if they were actual people" and would "speculat[e] on what they did offstage" (Riverside 23). Even the "absence of actresses" did not “inhibit Shakespeare's gifts" for creating dynamic female characters" (Riverside 24). Levin continues to glorify Shakespeare's skills by presuming he "lived and felt for" all his characters, as they "exist by virtue" of Shakespeare's emotions just as they "ask for our participation" in their own emotions (Riverside 24). The Riverside's continuous praise of all aspects of Shakespeare's writing paint the playwright as a genius wordsmith, but his additional portrayal of Shakespeare as a creator of life who feels the emotions of his characters puts the playwright on a level that is nearly godlike. This demonstrates the high regard the editors of the Riverside have for Shakespeare, and it assumes the anthology's reader will share the same appreciation for Shakespeare as a significant figure in the history of writing.

On the other hand, the Riverside appears to construct their readers to have little knowledge but an interest in the origins of Shakespeare's texts. The anthology includes a fifteenpage essay titled "Shakespeare's Text" by G. Blakemore Evans, dedicated to the history of early modern publishing of Shakespeare's texts. This essay introduces to the reader concepts such as "foul papers" and "fair copies" (Riverside 56) and describes the differences between the Quarto and Folio texts. In addition to Evans's essay, the Riverside devotes nineteen pages of scanned images from the First Folio and ten pages after the text of King Lear to highlight the textual 
variants. In contrast, the Pearson only briefly covers the topic, and the Bedford only provides one page featuring a single scene from the quarto that is not present in the folio text provided, which appears to merely serve as an optional topic for classroom discussion. This suggests that the readers constructed by the Riverside need to understand the process of early modern publishing and the revision process of Shakespeare's plays in the various forms, from the foul papers to the quarto text and the folio text, reaching to the editorial process of modern editors. This may be because the Riverside assumes a reader who already has the engagement and interest in Shakespeare's writing that the Bedford and the Pearson aim to instill in their constructed readers, and therefore the Riverside strives to take a step further into studying Shakespeare's works from a new approach. The essay also goes into detail about the complexity of the text of King Lear, reviewing the process an editor takes in choosing which version of the text to include, the quarto or the folio. Evans emphasizes that the best choices in editing King Lear, especially in a situation when words, lines, and passages appear in one text but not the other, involve maintaining the authorial intention, as reflected in his statement: “[T] he editor must now try to determine which of these texts offers the best authority for what Shakespeare wrote" (Riverside 64). This dedication to Shakespeare's original intention, while problematic, further demonstrates the reverence the Riverside holds for the playwright that is then projected onto the constructed reader to hold the same appreciation.

The critical introduction preceding the text of King Lear continues to approach Shakespeare as a highly-regarded writer, noting the play's "undeniable greatness" despite A.C. Bradley's claim that it was the "least popular" play of Shakespeare's "famous four" and that it was never played in its original form for about 150 years. Bradley states that King Lear is "Shakespeare's greatest achievement, but...not his best play," and while he finds it "inferior" to 
the other three most famous plays—Hamlet, Othello, and Macbeth—he sees King Lear "not as a play but as 'the fullest revelation of Shakespeare's power"' and is, therefore, "too huge for the stage" (Riverside 1297). The emphasis on Shakespeare's masterful craft is further developed in the fact that he explored elements of humanity, a notion recognized in the Bedford and Pearson anthologies. However, while the latter two anthologies explore this notion to convince the reader to identify with Shakespeare's work, the Riverside appears to explore this notion to express a shared appreciation for Shakespeare as an artist. The critical introduction again quotes A.C. Bradley, who deems King Lear as "the most terrible picture that Shakespeare painted of the world" (Riverside 1297). This appears to illustrate Shakespeare's genius as an artist who has the skill to be able to paint a reflection of the dark side of humanity through the composition of a play. At one point, the editors even refer to Shakespeare's skill for writing as "imaginative powers" that are devoted to the "incarnation of themes and images" (Riverside 1299), thus further illustrating how the editors put Shakespeare on a pedestal.

The previous examples illustrate how the Riverside appears to construct a reader who already has a foundational knowledge of Shakespeare's language and culture. However, while the Bedford and Pearson anthologies hope to instill a sense of appreciation in their constructed readers by providing features aimed to make Shakespeare's plays more accessible, the Riverside appears to construct a reader who already shares with the editors a strong appreciation for Shakespeare and thus the anthology provides features to take readers' foundational knowledge and appreciation for the bard to a higher level. This higher level includes different ways of approaching Shakespeare, such as the textual process his plays have undergone throughout the centuries. 


\section{The Norton Shakespeare (2016)}

Out of the five anthologies, the Norton's constructed reader appears to be the most influenced by the anthology's editor. Stephen Greenblatt, general editor of the Norton Shakespeare Edition, is one of the founders of new historicism, introducing the term in the early 1980s. It has been described in Greenblatt and Catherine Gallagher's book, Practicing New Historicism, as the "conceiving of cultures as texts" (Gallagher \& Greenblatt 8). This theory is clearly found in his approach to the Norton anthology. For example, the pleasures of seeing a play in the theater is credited to having "unparalleled access to the past" (Norton 75). Additionally, the entire concept of textual "origins" has historical implications and, therefore, has a relationship with the cultures of the past. Therefore, the study of textual origins and the variants in the original printed versions of Shakespeare's plays imply the conceiving of history as a text itself. For example, the Norton implies that approaching history as a text itself brings pleasure, as evidenced by the statement of hope to share with the reader "a sense of the further levels of engagement that close attention to the origins of the text itself can bring" (Norton 75). Therefore, the Norton conveys Greenblatt's new historicist approach to the reader by marketing the process of perceiving the past as a text as a significant part of the pleasure of experiencing Shakespeare.

Taking a concept that was previously studied in the Riverside and was briefly mentioned in the Bedford, the Norton appears to construct a reader who requires textual analysis of Shakespeare's quarto and folio texts in order to fully engage and take pleasure in plays with a textual history as complex as King Lear. Greenblatt states in the preface that the ultimate emphasis of the edition is on the "pleasure of reading," paying particular attention to "undergraduates who may be encountering Shakespeare for the first time" (Norton xix). Thus, 
Greenblatt has put effort into writing the materials such as the glosses, notes, and introductions to "facilitate understanding and hence to enhance liking" (xix). Evidently, Greenblatt believes that a significant part of the pleasure of Shakespeare lies in the text itself. Along with the 74page general introduction, there is a separate 18-page General Textual Introduction by assistant editors Gordon McMullan and Suzanne Gossett dedicated to describing the print house in Shakespeare's time and introducing the idea of textual variants between the quarto and folio texts, complete with scanned images of the pages. McMullan and Gossett argue that attention to Shakespeare's text is not only "an integral part of understanding the meaning of Shakespeare's works" but also "considerably enhanc[es] the pleasure of the reading experience" (Norton 75). Thus, the constructed reader of the Norton appears to be one who is interested in analyzing the textual variations of a play as a necessary step in both understanding and enjoying the experience of reading Shakespeare.

However, it appears that the constructed reader has little preexisting knowledge in the study of textual origins, as evidenced by the use of editors Gordon McMullan and Suzanne Gosett's introductory language in the General Textual Introduction. Examples include the sentence: "To understand how the printing process affected the texts we read, it helps to know how the two principal formats in which Shakespeare's plays were printed — folio and quartowere put together" (Norton 77), and the acknowledgement of the fact that a play can have more than one text "might seem odd" because "Surely there is only one Hamlet and that is the Hamlet Shakespeare wrote?" (Norton 75). This rhetorical question, written to reflect what the reader is supposedly wondering, implies that the editors are imagining a reader who is encountering concepts such as textual variants in Shakespeare's plays for the first time. 
Nonetheless, the editors believe that this knowledge is essential for their reader's pleasure of fully experiencing a Shakespeare play and thus provide the varying texts of Hamlet and King Lear for readers to compare in the print anthology. More variations of multiple other plays are also provided in the online edition. In the "General Textual Introduction," McMullan and Gossett provide an example of how the experience with Shakespeare is affected by "not only the choice of play but the choice of text of that play" (Norton 76) by placing the same passage from two versions of Othello side by side: "She gave me for my pains a world of sighs" (Q 1.3.146) versus "She gave me for my pains a world of kisses" (F 1.3.159). McMullan and Gossett note the effect the reader's choice to read the Quarto or Folio has on their reading experience. Whether one reads the "sighing Desdemona" or the "more ardent, kissing Desdemona" will influence their interpretation of the play, and therefore the study of the text's "material features" and the play's meaning are "inseparable" (Norton 86). The Norton constructs a reader, therefore, who appears to be able to critically engage with several versions of the play and thus recognize the different interpretations of character each version could produce, such as with the situation of the passive "sighing Desdemona" or the more assertive "kissing Desdemona." The Norton expects its reader to be intellectually stimulated by collating the separate versions of the text and the differing interpretations that result.

Other evidence that the Norton's constructed reader is intellectually stimulated by textual origins is the fact that King Lear is presented as three separate texts: the quarto, the folio, and a conflated version of the two. This appears to be so that the reader can compare them, analyze the editors' roles in constructing the texts, explore the decisions made by playwrights, editors, and printers, and "witness firsthand the historical transformation of what might at first glance seem fixed and unchanging" (Norton xxii). The introduction to the text includes a textual introduction 
describing the history of the play's text from the "foul papers" to the quarto to the folio, detailing the "reassigned speeches" and "omitted or cut scenes" (Norton 624) that the Folio offers that are not presented in the Quarto. Once again, this appears to be fundamental information provided to a reader who does not have prior knowledge on the subject but has a deep interest in learning more. The three separate texts of the play include the quarto text, the folio text, and a conflated version of the two texts, a feature that is not offered in any of the other four editions except for the Oxford's supplemental anthology, Complete Alternative Versions. This illustrates Norton's emphasis on the importance of studying the textual variations in the experience of reading a Shakespeare play.

Ultimately, the constructed reader for the Norton is one who does not have previous knowledge of textual origins and early modern printing but is intellectually stimulated by the process of learning more and by actively engaging in the processes of comparing the textual variants of the plays and how they affect interpretation. While the Bedford and the Riverside both provide brief introductions to textual origins, the Norton takes it multiple steps further by providing three versions of the full text of King Lear for their reader's reference. This demonstrates the significance that editor Greenblatt places on textual origins in terms of experiencing and taking pleasure in Shakespeare's plays.

\section{The New Oxford Shakespeare: Modern Critical Edition (2016)}

In contrast with the other anthologies, the Oxford constructs readers who appear to be from different disciplines not necessarily related to English literature but have the common quality of having picked up the Oxford anthology to read Shakespeare. In the General Editors Preface of the anthology, Gary Taylor of Florida State University, John Jowett of the University of Birmingham, Terri Bourus of Indiana University, and Gabriel Egan of DeMontfort University 
emphasize that many of Shakespeare's readers throughout the past four hundred years "are not, and have no desire ever to become, professional Shakespeare scholars or English teachers" (Oxford iv). The anthology further acknowledges that Shakespeare's readers consist of a variety of different people such as actors, artists, lawyers, philosophers, historians, politicians, psychologists, doctors, and scientists (Oxford iv). It appears that the Oxford's universal approach to accommodate people from these different disciplines is to provide features that illustrate aspects about the play that would only otherwise be perceived by watching a performance onstage. These features include side text demonstrating the manner in which certain pieces of dialogue have been performed in the past as well as lyrics complete with the notes on a staff whenever a character sings a tune. The editors compare their anthology to appetizers, "offering a small taste of many different dishes" so that their readers may "discover which flavours they find most appealing" and "which they want to explore more fully in their own kitchens" (Oxford iv). Their hope is for their anthology to "reintroduc[e] Shakespeare to the great variety of readers in our time" and that it "stimulates the future questions and debates that will keep Shakespeare a part of our ongoing conversations" (Oxford v). Therefore, it appears that the constructed readers of the Oxford come from a variety of different disciplines, but all readers will find their favorite "tastes" through the specific features offered in the edition that appeal to them and pursue further research beyond the anthology on their own time. A quote by editors Gary Taylor and Terri Bourus sums up their goal for the features they provide the reader, stating: "Rather than tell readers what to think, we identify a range of issues to think about" (Oxford 45). Therefore, the reader addressed in the Oxford anthology is able to use critical analysis to draw their own conclusions based on a snippet of information offered in the Oxford. 
An example of small snippets of information that readers build upon on their own can be found in the section preceding each play. In lieu of a critical introduction, the Oxford provides a collection of quotations between the years of 1592 and 2016 that represent "different critical perspectives, different disciplines, and different historical periods" (Oxford 46). It is as if the reader were in a theater watching the play alongside different figures in history and overhearing their remarks that, in many cases, are quite representative of the time period from which they are from. This feature may have been influenced by the interests of the general editor, Indiana University professor Terri Bourus, about the historical reception of early modern drama, especially in the late sixteenth and early seventeenth century. In the general introduction section, “Why Read This Complete Works?” Bourus and general editor Gary Taylor state that they hope the reader "will find, in each bricolage, at least one critic you want to investigate on your own, and at least one you find so irritating that you cannot resist arguing against them" (Oxford 46). Therefore, it appears that Bourus's enthusiasm for analyzing the reception of early modern drama throughout history is projected onto the reader of the anthology so that the editor and reader may share enthusiasm on this subject. A few quotations, Taylor and Bourus state, are "deliberately difficult" because "difficulty of thought and language is sometimes necessary and rewarding (as Shakespeare demonstrates)" (Oxford 46). The constructed reader, therefore, will be not only critically engaged in the text but passionate about pursuing their own additional research, finding the challenge of studying Shakespeare rewarding. As opposed to the Bedford's constructed readers, the Oxford's do not necessarily require a critical apparatus preceding the plays to stimulate thought and curiosity, and yet are able to conjure their own critical insight by reading a variety of perspectives. Choosing from the quotations presented in King Lear, for example, a reader who is interested in feminist studies may find interest in two opposing quotes, 
one from 2013 by Ewan Fernie, and another from 1996 by Jane Smiley. Fernie refers to Cordelia as a "saint" (Oxford 2350) whereas Smiley, author of $A$ Thousand Acres (1991), a retelling of King Lear, calls Cordelia "ungenerous and cold" (Oxford 2348). Smiley appears to find offense in Shakespeare's portrayal of the older sisters as "figures of pure evil according to conventional wisdom," while their supposedly evil actions are "familiar" to Smiley herself, specifically "in the scene where they talk between themselves about Lear's actions, and later, when they have to deal with his unruly knights" (Oxford 2348). She states further: "They were women, and the play seemed to be condemning them morally for the exact ways in which they expressed womanhood that I recognized" (Oxford 2348). The Oxford implicitly encourages readers interested in gender studies to read Smiley's novel, A Thousand Acres, and analyze how she portrays the character equivalents of Goneril and Regan. The reader can then explore whether Smiley condemns her characters in the same way Shakespeare condemns his characters, or if Smiley paints her characters as evil, not because of their gender, but in other ways as well.

The Oxford imagines readers who desire or require detailed stage directions to create the illusion of perceiving the play as if performed onstage. The anthology provides what is called Performance Notes, which "call attention to more complex staging possibilities" such as the age of characters, costumes and props, or theatrical interpretations (Oxford 47). This material suggests that the constructed reader is either an actor or merely prefers to have a clear image of the play in performance. For example, in a scene of dissonance between Edgar, Gloucester, and the Steward, editor John Jowett adds a stage direction that creates a lively image of the scene: "Edgar probably stands between Gloucester and the Steward, holding Gloucester with one arm and challenging the Steward with the other, or pulls Gloucester away from the Steward" (Oxford 
2417). This annotation appears to provide additional insight to the tension in the scene that the editors assume might otherwise have only been vaguely perceived until the Steward is killed.

The Oxford's constructed readers, therefore, come from a variety of disciplines but are all interested in and willing to actively engage in a discussion with the text not only in response to critical apparatuses provided by the editors but with extra material that fuels the readers to conjure their own critical thoughts and pursue further research.

\section{Analyzing the Readers Depicted in Shakespeare Anthologies}

Though the five anthologies construct readers who overlap in some areas and diverge in other areas, it appears that they can be sorted into two categories. The first category presents Shakespeare as a "universal" writer who transcends history because of his masterful creation of characters and dramatic situations that speak to all generations, as depicted in the Bedford, Pearson, and Riverside. The second category presents the study of "Shakespeare" as a field of historical, literary, textual, and cultural study, as in the Norton and the Oxford.

It is important to note, especially in the cases of the Bedford, Pearson, and Riverside anthologies, the difficulty of using the word "universal" to describe Shakespeare's writing to appeal to their constructed readers. Many topics in Shakespeare's writing that are considered "universal" are only so for certain Western audiences, perhaps even those who are white and male. This is also a problem in the Riverside where readers are asked to worship Shakespeare because of his depiction of the supposed universal human experience. If students of all different demographics are told in a classroom that they should appreciate Shakespeare for his "universality," they will find that there are many experiences depicted in Shakespeare's works that are not familiar to them. However, it appears that approaching Shakespeare in this way may be more cost-effective for the publishers and more ideal for the consumer. 
To determine this, we must first consider one factor that may have played a role in the reader's construction: the multiple roles that make up the publishing process. The editor does not have complete control over the final product that is sold to the consumer. Until the 1990s, the traditional model for academic publishing positioned the commissioning editors as the source of power and authority (Thompson 134). However, when the library market eroded and the sales of scholarly monographs declined, the hierarchy shifted, and now sales and marketing staff play a more significant role in the publishing and packaging of a textbook in order to improve the financial contribution of a project. Some consequences of this hierarchy shift include cutting illustrations, especially those that are full-color, as well as the length of the textbook to reduce the cost of production (Thompson 134-137). This may have been the case with many, if not all, of the anthologies, as printing illustrations, especially those in full color, have proven to be expensive. The professionalization of marketing removed authority from editors and, therefore, the final product may be different from the editor's original plans, as many of the decisions are made to shape the textbook as a product that must remain within a certain budget to ultimately result in profit.

With this in mind, it appears the anthologies that approach Shakespeare as a "universal" writer are more likely to use their budget on images, whether in black and white or in color, of theatrical performances and early modern culture for the purpose of bridging the gap between Shakespeare's time period and twenty-first century readers. The Pearson, for example, features sixteen glossy pages of images in full-color while the Riverside invested in a total of forty glossy pages of images, sixteen of these in full-color. It may be due to this investment that both editions decided to print its text in double columns to save investment in pages, the Pearson totaling in 2,016 pages and the Riverside in 2,057 pages. The Pearson, in its seventh edition, is sold on the 
Pearson Education website for $\$ 134.40$ whereas the second edition of the Riverside, which has not been updated since its publication in 1997, sells at Barnes \& Noble for $\$ 36.90$. In between these two prices is the Bedford at $\$ 74.73$, which is the only anthology with color on every page, albeit a single color - a light shade of blue highlighting side text and supplementary material as well as the page headings and line numbers. This certainly adds a visually pleasing element to the anthology, the hint of color on every page drawing the reader into important samples of paratext detailing analyses of key passages or descriptions paired with images of scenes in action on nearly every page. The decision to add this hint of color and images with supplementary text appears to be worth the added cost for the sake of the anthology's constructed reader, as the anthology aims to visually capture and maintain a reader's interest just as its textual content detailing the relevance of Shakespeare to contemporary time period does. It appears that the Bedford makes up for the costly add-ons by publishing the anthology in paperback, reducing the textual apparatus to shorter segments interspersed throughout the anthology, and keeping the length at 1,856 pages - the shortest length of all the five anthologies. Not only do these decisions reduce cost, but they also appear to make the anthology even more appealing to the reader they are marketing to, as shorter segments of paratext interspersed throughout the anthology might keep their reader more interested than a lengthy paratext compiled into a general introduction. The reduced number of pages, too, makes portability more of an option than anthologies over 2,000 pages.

While the Norton and the Oxford do have images in their anthology, they are kept to a minimum and are all in black and white. These anthologies that approach "Shakespeare" as a historical, literary, textual, and cultural study appear likely to instead spend their budget on large quantities of pages featuring text-based material, such as several full-length texts of a single play 
or pages upon pages of historical background, as in the Norton. It is this reason that the textbased anthologies appear to be longer than the anthologies that approach Shakespeare as a "universal" writer. The Norton sits at 3,536 pages and the Oxford at 3,382 —on average, about 1,500 pages more than the Pearson, Riverside, and Bedford. Therefore, theory-based anthologies appear to be heavier in weight than the other anthologies, which may be difficult for their readers who may need to carry the book to class. The Norton appears to take this into account, however, and offers a paperback version in four volumes: Comedies, Tragedies, Histories, and Romances and Poems for a price of $\$ 79.40$, about thirteen dollars fewer than the one-volume edition (\$92.50). This appears to be more convenient, as a reader has the option for a slightly lower price to carry around a lighter book particular to the play they are reading in class. However, four volumes can be difficult and inconvenient to manage, and a student may prefer the solidarity of a single-volume edition. The Oxford, on the other hand, offers readers two completely new editions as supplementary texts to the Modern Critical Edition examined in this thesis. The Critical Reference Edition (\$300) contains 3,979 pages displaying the text of the complete works of Shakespeare in its original early modern spelling, and the Authorship Companion (\$190) contains 600 pages of detailed evidence behind the editorial choices made in the Oxford's Complete Works of Shakespeare. Assuming the reader is interested in these materials, it would cost them an additional $\$ 490$ to access a hard copy of it along with the Modern Critical Edition, totaling approximately $\$ 570$ total for the complete experience, which many readers may not be able or willing to pay, especially when similar features are found in the Norton anthology for under one hundred dollars. The editors of the Oxford do acknowledge, however, that while the options are available, "most readers" are interested in the Modern Critical Edition only (Oxford 55-56) and are not required to purchase the supplementary anthologies if they do not wish to. 
Ultimately, while the theory-based anthologies such as the Norton and Oxford anthologies produce material that will intellectually stimulate their constructed readers, such as several versions of a single play and lengthy historical context, the additional pages result in an excessive weight that these same readers may find difficult to transport to class, thus risking a chance of driving their target audience toward lighter anthologies. The features and constrictions of the anthologies that approach Shakespeare as a universal figure, on the other hand, appear to be beneficial for their readers. This appears to suggest that perhaps anthologies that approach Shakespeare as a "universal" figure use methods that not only work for the readers they construct but are also more cost-effective. 


\section{CHAPTER THREE: THE READERS CONSTRUCTED BY SHAKESPEARE PEDAGOGY}

In this chapter, I closely examine the reader constructed within the field of Shakespeare pedagogy. Scholars such as Rex Gibson and Michael Flachmann seem to hold the firm belief that Shakespeare's plays are best taught as a script so that readers of all ages can better grasp the play as a performance. In this sense, active performance activities are encouraged to be held in the classroom. In contrast, scholars such as Anthony B. Dawson and Ann Thompson critique this approach and encourage a more traditional approach of teaching Shakespeare as a literary text. In this chapter, I will closely examine the readers constructed on both sides of the conversation. I ultimately argue that the constructed readers in Shakespeare pedagogy require both approaches of Shakespeare as a performance and as a literary text in order to successfully learn Shakespeare.

\section{Performance-Based Shakespeare}

In his book, Teaching Shakespeare: A Handbookfor Teachers (2016), former Cambridge professor Rex Gibson appears to be writing for professors who have very minimal experience with teaching Shakespeare. The first chapter, for example, is entitled "Why Teach Shakespeare?" and appears to imply that the instructors reading Gibson's book may question the relevance of Shakespeare in the contemporary classroom. In the introduction, there are nine contributions by scholars who hold the late Gibson in high regard. Stanley Wells, University of Birmingham professor, calls him a "major pioneer in the teaching of Shakespeare in schools" (Gibson xiii). University of Manchester professor Rob Smith calls him "the greatest influence on [their] work in an English classroom" (Gibson xi). Additionally, Gibson’s suggested activities and approaches are called "invaluable" and "effective" and, as Senior Advisor of the Creative Programs at Shakespeare's Globe, Fiona Banks, says concisely, "they worked" (Gibson xxii). 
Gibson appears to believe that the closer the experience of Shakespeare's play in the classroom is to the original experience of the play in Shakespeare's time period, the more beneficial it is for the depicted reader. This is evidenced by Gibson's reasoning for the ineffectiveness of reading the play to be because "Shakespeare wrote his plays to be performed" and "to be brought to life on stage before an audience" (8). Additionally, Gibson suggests that an instructor should approach the endeavor of learning Shakespeare as a social process as opposed to the solitary process of reading the play to oneself. Providing students with opportunities to work together in pairs or groups "reflects Shakespeare's own working conditions as he and his colleagues at the Globe rehearsed together to produce a performance" (12). Thus, throughout the book, Gibson suggests a variety of activities for both high school and college classrooms that involve social and performance-based learning. Several activities include pairs of students sharing a soliloquy and speaking a single word or short phrase at a time, alternating between the pair at each punctuation mark (12); groups of students imagining and enacting alternate endings to the plays (22); and students staging or interpreting a scene from different points of view (22). Therefore, Gibson appears to depict a student who is not only comfortable with engaging in group activities and performing in front of the class but requires these activities in order to fully engage with Shakespeare's text.

It also appears that the reader depicted by Gibson would be intimidated by lengthy introductions in anthologies of Shakespeare's complete works. Gibson critiques anthologies with "lengthy introductions" and "extensive footnotes" as more "scholarly" editions that "promote teaching methods that explain and analyse, rather than enable students actively to inhabit the imaginative worlds that Shakespeare offers" (8). Such methods, Gibson claims, are more suitable for postgraduate study and have a "demotivating effect" on students who have not reached that 
point in their academic endeavors (8). Therefore, Gibson appears to depict Shakespeare's readers as needing to learn key concepts in a social learning environment by engaging in group performances and interactive activities as opposed to reading the general introductions that may offer the same information.

California State University Bakersfield professor Michael Flachmann appears to share Gibson's belief that "plays are intended to be acted before audiences" and, therefore, a performance-based approach is beneficial for the undergraduate or high school reader of Shakespeare that he depicts (Flachmann 644). In his essay, "Teaching Shakespeare Through Parallel Scenes," Flachmann emphasizes the importance of approaching the play in the classroom as an actor would in terms of being "alert for clues" that are "implicit in the language of the play" that will ultimately "guide them to an understanding of motivation and action on stage" (644). Flachmann appears to depict a reader of Shakespeare who requires performance activities in order to identify with the characters and scenarios depicted in Shakespeare's plays and, ultimately, engage with Shakespeare's plays.

Flachmann suggests a classroom activity that engages students in the process of identification with the characters and scenarios in Shakespeare's plays involving "parallel scenes," which he deems "one of the easiest and most effective devices" to immerse students into the action of a play written by Shakespeare (Flachmann 644). A parallel scene involves the "personaliz[ation]" of a dramatic scene in a Shakespearean play by "converting it from an obscure time and place to a parallel setting in the comfort and security of the present" (645). In other words, Flachmann asks his students to personally identify with the situation in which the characters in the play find themselves and construct an equivalent contemporary situation that students find recognizable, and then improvise contemporary dialogue that reflects the 
"emotional rhythm" of the original scene (645). Flachmann encourages the use of props whenever possible for the purpose of "heightening" the students' "sense of reality" so that they may fully "experience the roles" of these characters (646). Once the students make connections with the modern parallel scene, their focus is then transferred back to reading Shakespeare's original scene. Flachmann notes the potential "stunning results" as students return to reading the original Shakespearean dialogue: a "real breakthrough" in the students' understanding (646). Flachmann notes a common revelation on the students' part: "So that's what the scene means. I've never understood it so clearly before" (646). He insists that this revelation is because the students have "learned to find themselves in the play" and have realized that "Shakespeare is portraying the lives of characters who are very much like all of us" (646). Thus, according to Flachmann, by "becoming 'actors'," student readers "made Shakespeare their contemporary" in order to "find a pathway" into Shakespeare's often elusive world (646). In other words, for these scholars, shaping one's thinking into that of an actor is the key that unlocks the door to the clarity of Shakespeare's words through the channel of identification.

Not only does Flachmann suggest that students should temporarily adopt the thought process of an actor for the purpose of understanding Shakespeare, but he appears to depict students as able to embody an actor's maturity and comfort level when performing a scene with other students:

The student actor and actress playing the parts of Ferdinand and Miranda should be asked to sit facing each other, holding hands (if possible). They should then perform their modern parallel scene again, this time unencumbered by physical action. During the scene, each should respond as much as possible to the physical reality of his acting partner: "You have 
beautiful eyes." "You seem strong and quiet—I like that in a man." The purpose here is to encourage students to experience the roles by actually discovering positive qualities in their partners. This, after all, is what Shakespeare's Ferdinand and Miranda are doing in the scene (Flachmann 646).

Flachmann's suggestion to assign students to improvise the dialogue for such an intimate scene while encouraging physical contact suggests that the student of Shakespeare he imagines has the ability to approach the scene with the comfort and maturity of an actor. While Gibson's and Flachmann's methods both approach Shakespeare's plays as a performance, it appears that their teaching style is distinguished by one particular factor: Gibson appears to acknowledge that the reader of Shakespeare he depicts are students in a classroom while Flachmann appears to treat his reader of Shakespeare not as students but as professional actors. This is evidenced in the manner in which each researcher approaches his activities. Gibson appears to approach the in-class performance activities as a social endeavor in which students divide into pairs and groups to write alternative endings and engage in group activity. Flachmann, however, approaches the "parallel scenes" activity as if students take on the persona of an actor and become the character, engaging in method acting the way a professional actor would. While this has its beneficial qualities, it can have its disadvantages. These disadvantages will be discussed at the conclusion of this chapter. 


\section{Literary Critical Shakespeare}

In his essay, "Teaching the Script” (2009), University of British Columbia professor Anthony B. Dawson describes the apparent "shift" in Shakespeare studies from approaching Shakespeare's plays as a literary text to approaching the plays as a script (Dawson 78). Dawson implies that when he began teaching at Harvard University in the 1970s, his performance-based

teaching methods were "by no means the norm" because "the so-called 'new-criticism' still held sway" (77). "Nowadays," Dawson says in the 2009 essay, "the situation is reversed" (77). Dawson implies that, over the course of thirty or more years, the approach of Shakespeare's plays as scripts meant for performance became "commonplace" (83). Dawson argues that, as of 2009, students need to be convinced that Shakespeare's plays are "not only scripts, but literary works with a long history, poems as well as plays," and that instructors need to emphasize the "relations between these works as scripts, and as something more than just scripts" (78). Dawson's suggested solution is to "bridg[e]" the "unnecessary split...between the literary and performance aspects of Shakespeare's texts" (83). In this sense, Dawson appears to agree with certain performance elements depicted in Gibson and Flachmann's arguments but adds a layer of textual analysis to his in-class performance activities. Dawson's depiction of Shakespeare's reader, therefore, is one who must be convinced that Shakespeare's plays are not just a performance but also a literary text that has undergone an evolutionary process from Shakespeare's hand to modern publications of the work.

With Dawson's pedagogical research, he imagines a reader who has minimal prior experience or knowledge of textual variants in Shakespeare. This is evident in Dawson's decision to let students' perplexity lead the way into the issue as opposed to assigning them to 
read the preliminary section in the assigned 1987 Oxford edition of Hamlet edited by G.R. Hibbard, which explains the origin of the text. Dawson recalls:

One student actually wondered aloud whether Prof. Hibbard had not made a hideous mistake and forgotten to print the long soliloquy that he (the student) could plainly see in the [Riverside Shakespeare anthology] held by the young woman beside him... Of course it didn't take long to point out that the speech in question is indeed printed in Hibbard's edition, but only as part of an appendix....So Hibbard has clearly not made a mistakehe is simply following a different early version. (79)

Once the constructed reader learns about textual variants, however, it appears that Dawson sees the reader as being "awed" (80) and "liberat[ed]" (81) by the discovery of how textual variants can lead to different interpretations of a play. Dawson's reader is motivated then to produce and perform their own scripts with these discoveries in mind. In addition, Dawson insists that "despite their shyness about actually performing in front of their classmates, and their terror about remembering their lines, the students love doing this" (81). Dawson does note, however, that "some students put more into the project than others," but generally, the majority of students exert a "level of cooperation and collaboration within groups" that is "typically impressive and fair" (82).

In her article, "King Lear and the Politics of Teaching Shakespeare” (1990), Ann Thompson, similar to Dawson, appears to construct a reader of Shakespeare who requires a shift in perspective from approaching Shakespeare's plays as a performance to a literary text. However, where Dawson conducts the literary approach by convincing students of the various forms the text underwent throughout the history of the printing process, Thompson's literary 
approach involves the use of critical theory. The first-year undergraduate students depicted in the 1990 article appear to have come into Thompson's Seventeenth-Century Literature course at the University of Liverpool "firmly committed to the view of Shakespeare as universal and ahistorical" (142-143). This is a perception that these students appear to have learned from the prerequisite course in high school, Advanced Level English, in which they all, Thompson claims, received a high grade. It is also a perception that Thompson deems problematic, as she muses: "How shall I attempt to persuade them otherwise?"

An example of this belief in action is evidenced by Thompson's being "assured" by several of her students that the knowledge of seventeenth-century history is "not necessary" to "appreciate" Shakespearean plays. This is a perception that a new historicist approach would argue against. According to Robert Dale Parker's How to Interpret Literature, it is not only knowledge of a text's historical context that is necessary for interpreting it but also an understanding of how texts influence history (Parker 220). Thompson's constructed readers' dismissal of history as mere "background" or "context" to the play is more in line with the beliefs of what new historicists call "old historicism," in which it is believed that "literature merely reflect [s] the history" (Parker 219). Thus, Thompson suggests that the students she depicts would benefit from studying or at least following the principles of a critical theory such as new historicism in a classroom that teaches Shakespeare. However, Thompson appears to suggest that persuading students in this direction is not easy because students appear to be firm in their beliefs. This is evidenced by Thompson's statement: "Some students have been stimulated by [the theoretical approach], while others have merely been confused" and "reluctant to spend time on what they think of as mere 'background' to the literary texts" (144). 
In addition to new historicism, Thompson also appears to suggest that a cultural materialist approach would best benefit the depicted reader of Shakespeare when introducing the textual variants of Shakespeare's plays for the first time. Thompson depicts her students as being "startled" by the discovery that the anthology used in class-a 1986 edition of the Oxford's Complete Works of Shakespeare — contained two different versions of King Lear, similar to the students depicted in Dawson's study (145). However, whereas Dawson approached this through a performance activity, Thompson claims that introducing the quarto and folio texts of Shakespeare's plays is for the purpose of introducing issues such as the "transmission and stability of seventeenth-century texts" and the "ongoing shift from manuscript to print culture" (145). Thompson describes her assignment as not only collating the texts but examining the "presentation and annotation of Shakespeare by comparing photocopied extracts from the Quarto and the Folio with modern edited versions" (145). In other words, Thompson asserts that the readers of Shakespeare in her classes benefit from studying the economics of the printing press over the course of history as its own text. Furthermore, Thompson claims "many" of the readers she depicts "enjoy this 'microlevel' investigative approach" (145). Therefore, not only is this approach presented as beneficial for Thompson's student readers, but these readers also appear to enjoy it.

In addition to new historicism and cultural materialism, Thompson appears to believe that feminism is another critical approach that would be beneficial for the constructed reader of Shakespeare to adopt. Thompson recalls an instance in which a female student stated that she had been "specifically taught" in her high school Advanced Level English course that modern feminism was "irrelevant" to any reading of the play The Taming of the Shrew (143). Thompson suggests the importance of maintaining feminist criticism in the classroom by adding to the 
curriculum an anthology of women's writing "that includes autobiographical and prophetic writing as well as the expected poems and play" (143). Thompson states that this will: probably further fuel debate about the canon and will introduce some new questions about the extent to which twentieth-century feminist criticism is an appropriate tool for reading seventeenth-century texts, because, of course, we are not just teaching 'more history' but doing it in the context of recent 'theoretical' approaches to the teaching of literature that have been particularly influential in the study of this period (143).

Therefore, Thompson presents student readers as potentially resistant to the idea that modern-day feminism can be applied to an early modern text and, therefore, it is the instructor's role to convince them otherwise.

Thompson suggests that the supposed perception that Shakespeare is universal appears to be met with "resistance" when her students are comparing the themes of King Lear to issues that are "closer to home," specifically in terms of "today in Liverpool, a city of high unemployment and appalling economic deprivation" (146). Thompson claims that readers of Shakespeare "prefer to distance the text from the sort of debate that would oblige us to confront directly the continuing inequalities of the British class system" (146). Therefore, it appears that Thompson's constructed reader is hesitant to approach Shakespeare's plays as anything more than a fictional story that only belongs in the era in which it was written.

Dawson and Thompson both state that the contemporary reader of Shakespeare needs to be convinced that Shakespeare's works are not only plays meant to be performed but also literary texts. However, it appears that the readers depicted in Thompson's scholarship are much more resistant to approach Shakespeare through a lens that is different from what they were previously 
taught while the readers who Dawson depicts are more open to the idea. The reasoning behind this is that Dawson combines textual analysis with performance activities, so building on concepts of which the students are familiar may have been the reason why the readers depicted in Dawson's scholarship were more open to adopting a literary approach to Shakespeare. The reader depicted in Thompson's scholarship, however, remain firm to the beliefs of Shakespeare that they were previously taught, requiring a stronger push from their university professors to shift their perspectives toward a more literary approach. This may be because Thompson does not appear to use performance activities in the classroom in addition to the theoretical lens, so the students depicted in Thompson's research may have been less willing to fully transfer to a different approach to Shakespeare.

\section{Analyzing the Readers Depicted in Pedagogical Scholarship}

The four scholars who approach Shakespeare's plays either as a performance or as a literary text each construct readers of Shakespeare who may not be representative of "real" students of Shakespeare. Because there are no descriptions of the research process or the demographics of the students in question, it is difficult to determine whether the results are biased and to what extent. For example, the seemingly revolutionary effects of Gibson's teaching methods are not documented in any specific detail, and there is no explicit statement about Gibson's research process. Furthermore, the explicit acknowledgement of students possessing different learning needs does not go much beyond Gibson's statement in the introduction:

The professional teacher's skill lies in the subtle and thoughtful adaptation of content and method to suit the circumstances and the unique nature of their own students. The many practical examples in this book are offered 
in the knowledge that teachers will adapt them in ways suitable for their own classrooms (Gibson vi).

This concept is a step in the right direction, but it also falls short in acknowledging that the differences in learning needs do not only vary from class to class but also student to student. There is no acknowledgement of the possibility that there may be students who may not benefit at all from performance-based activities due to a variety of reasons, whether it be social anxiety, a lack of comfort with performing with or in front of their classmates, or any other factors that may hinder a student from learning through performance-based activities. Gibson's depiction of readers as learning best through performance activities also disregards those who may prefer to learn by engaging in solitary reading as opposed to group performance activities. Gibson does not seem to acknowledge that, while there are students who are daunted by reading lengthy paratextual material, there may also be students who are daunted by performance-based activities. Similarly, Dawson does not discuss how to encourage those students who prefer to learn through solitary reading or are intimidated by performing scenes in front of their classmates. Dawson instead suggests that these students will eventually enjoy the assignment.

Flachmann's research is similar to Gibson's and Dawson's in the sense that he disregards the possibility that performance-based activities may not always be the best way for certain students to learn Shakespeare. In the "parallel scenes" activity depicted in Flachmann's essay, the students appear to be engaging in acting out a scene that is very intimate, and it should be taken into account that it is possible for boundaries to be crossed when a student makes an improvised remark or physical gesture that brings 
discomfort to another student. When putting students who are undergraduates or younger into such scenarios, it is important to remember that many of them are not actors and, in many cases, cannot be expected to perform certain scenes with the integrity or comfort level that a trained actor would. While planning performance activities for a classroom of undergraduates, it is important to consider the possible scenarios that may arise that could ultimately hinder a positive learning environment.

\section{Comparing the Readers Constructed in Anthologies and Pedagogical Scholarship}

Upon analyzing the readers constructed by the five Shakespeare anthologies and in pedagogical research, one notices that the areas in which they overlap and the areas in which they diverge are very telling of who the editors and researchers believe to be the Reader of Shakespeare. One quality that is found in the constructed reader in both pedagogical research and in most of the five anthologies is to perceive Shakespeare's plays as scripts for performance. The Bedford, for example, provides images of various performances of a single play. In King Lear, there is an entire page dedicated to images of various interpretations of the Fool's character-a seventeenth-century woodcut of Archie Armstrong, Fool at the court of King James I; Antony Sher in Adrian Noble's production for the Royal Shakespeare Company (1982), clad in clownish clothes complete with white face paint, red lips, and a rubber nose; and Linda Kerr Scott in Nicholas Hytner's production (1990), dressed in dark tones with a scarf tied around her head (Bedford 1350). This page provides readers with the tools to see how the character has been interpreted in previous performances—-loud and clownish as with Antony Sher, or more toned down as with Linda Kerr Scott. It also demonstrates how roles are not necessarily genderspecific, which creates more opportunities for the interpretation of a character. In addition to the 
theatrical images, the Bedford also provides an essay called "Staging Shakespeare" that demonstrates to readers how an actor approaches reading Shakespeare's plays:

To breathe fresh life into Shakespeare's language, actors study the text for hints. For each line and every speech they will ask what motivated it. What was said in the speech immediately before to inspire it? What does the character intend to accomplish with these words, or what does he unintentionally betray? What evidence is there that the words are thoughtful or thoughtless, playful or serious, earnest or sardonic, honest or misleading, self-revealing or self-deluding? (Bedford 1546).

It would seem that the readers depicted in Gibson and Flachmann's research would find the images of certain scenes in action to be useful for them, as immersing oneself in the mind of an actor would provide a new way to read and interpret Shakespeare that would connect them more to the characters and language, and, therefore, meaning.

The Oxford could also accommodate a reader who approaches Shakespeare's plays as a performance because it provides annotations that detail theatrical aspects, such as how a piece of dialogue was delivered by a historical actor, or more detailed stage directions or suggestions about the use of props or scenery. For example, toward the end of Edmund's soliloquy in scene two, there is a stage note directing the entrance of Edgar, upon which Edmund states: "Edgarand out he comes like the catastrophe of the old comedy" (2.110). The annotation comments on Edmund's possible reasoning for uttering Edgar's name: "Edmund might respond to seeing Edgar enter, or, if 'Edgar' is spoken before the entry, either call Edgar, or ponder the name as he speaks to himself" (Oxford 2361). This demonstrates the various ways in which an actor may interpret the piece of dialogue. In a class activity proposed by Gibson or Flachmann, the students 
depicted in the research may choose to read the dialogue differently based on these suggestions and may perhaps gain insight into the character or scene in the context of the play as a whole.

Much of the Pearson's and Riverside's insight into engaging with the play through theatrical aspects involves viewing performances of the plays, either in film or on stage. The Pearson, therefore, offers features such as sixteen pages of full-color images of a selection of twelve different Shakespearean plays in performance in the General Introduction as well as an eleven-page appendix entitled "Films and Videos as a Guide to the Study of Shakespeare," a list of performances of Shakespeare's plays that students may choose to view. The Riverside similarly dedicates eight pages of full-color images of Shakespeare's plays in action as well as an eighteen-page appendix entitled "Shakespeare's Plays in Performance: From 1970." The latter, as in the Norton, appears to be a recollection of history as opposed to an analysis of the strategies actors use to engage in a text, as in the Bedford.

The Norton demonstrates theatrical aspects of Shakespearean plays but to a lesser extent, and so the readers imagined by Greenblatt may not fully align with those described by Gibson or Flachmann. The Norton does, however, state its acknowledgement of the performative aspect of Shakespeare's texts:

...[A] crucially important dimension of Shakespeare's texts, as everyone grasps, is that they were originally intended for performance. Hence the brief discussion in the General Introduction of the theatrical scene Shakespeare encountered and helped to transform is now greatly enriched in 'The Theater of Shakespeare's Time,' a lively and original essay by Holger Schott Syme (Norton xxiv). 
The 26-page essay by Syme discusses the history of the theatre in Shakespeare's time rather than suggests that students engage in a frame of thinking like an actor. Syme's essay also does not imply the requirement to think like actor to fully engage with a Shakespeare text. The Norton's only dedication to approaching King Lear as a script for performance is a half-page "Performance Note," in which Greenblatt offers information about how previous performances of King Lear chose to emphasize different themes in the play, which therefore brings about different emotions from its audience. Greenblatt states:

Productions featuring sympathetic treatments sometimes give religious significance to Lear's atonement and death, or present a fractured fairy tale pitting Lear and Cordelia against a pair of matching harpies. Such choices clarify the audience's sense of justice (Norton 625).

The brevity of this discussion may suggest that, like the Syme's essay, the Norton may have included this section to pique their reader's interest but does not necessarily find the performance approach to be crucial for their constructed reader's engagement in the play. The anthology's images for King Lear, for example, are not of the play in performance but instead a total of three black and white images of early modern paintings: one a muscular woman wearing a crown depicting Cordelia in Raphael Holinshed's Chronicles of England, Scotland, and Ireland (1577); an illustration by John Cypriano of a man stargazing while two men, regally clad, appear to be conversing amidst the presence of a horned creature (1595); and a portrait of Tom Durie, the jester of Anne of Denmark, by Marcus Gheeraerts the Younger (1614). Unlike the other anthologies, the Norton's images are not for the purpose of illustrating how the scenes have been acted in the past but instead for the purpose of illustrating how Shakespeare's plays have inspired artwork and its connection to history, an editorial decision perhaps inspired by Stephen 
Greenblatt's new historicist perspective. The readers depicted in Thompson's research, therefore, may find the Norton anthology useful because of its new historicist approach in the general introduction as well as the provision of three versions of King Lear along with the information about the economics of the printing press found in the General Textual Introduction, which depicts a cultural materialist approach.

The students constructed in Shakespeare pedagogical scholarship as needing to understand the relevance of Shakespeare to contemporary times is only covered in two of the five modern Shakespeare anthologies. Gibson and Flachmann's depicted reader may find assistance in the Bedford and Pearson in terms of identifying with Shakespeare's characters in order to understand and appreciate the Shakespearean play. The Bedford and Pearson's aim to use pathos to draw on the reader's emotions suggests to readers how they might be feeling towards the characters as they read. The constant referral to Shakespeare's depiction of humanity proposes to their constructed reader that Shakespeare is, indeed, relevant to them in the sense that we all share a common humanity that some scholars such as Gibson may refer to as "universality" (Gibson 16). While the Riverside approaches this "universality" in a way that highlights Shakespeare's skill, the Norton or Oxford do not construct a reader who requires identification with Shakespeare's characters to understand the plays and instead prioritize textual analysis, as in the Norton, and researching the historical reception of Shakespeare's plays in performance, as in the Oxford.

Another aspect of the depicted reader that pedagogical scholarship describes is that anthologies with lengthy introductions and extensive footnotes are more suitable for postgraduate study and can be overwhelming for undergraduate students. Yet, each of the five anthologies except for the Bedford contains exactly these qualities and thus imagines a reader 
who is not overwhelmed by this information and in fact needs it to effectively read and understand the plays. The Pearson, for example, begins with a 91-page, double-columned General Introduction, and the Riverside's 25-page General Introduction and additional 50 pages of literary criticism along with the Norton's 118-page and the Oxford's 58-page General Introductions demonstrate for themselves that they are most likely not suitable for the student Gibson constructs in his research. Gibson states that editions with "lengthy academic introductions"

promote teaching methods that explain and analyse, rather than enable students actively to inhabit the imaginative worlds that Shakespeare offers... The scholarly model may be suitable for postgraduate study, but it has had a demotivating effect on generations of school and college students. (Gibson 8)

Therefore, the reader Gibson depicts in his research would appear to be discouraged by the lengthy general introductions in these four editions to the point where they may not wish to continue their assigned readings. The Bedford appears to be the anthology that best suits Gibson's readers, as it is the only one without a traditional General Introduction but instead with a textual apparatus that is interspersed throughout the anthology in short segments. Additionally, this textual apparatus engages with students' imaginations, as it includes images of the play being performed and descriptions of theatrical interpretations, as stated previously.

Another notable difference between the constructed readers is that the Norton and, to a lesser extent, the Riverside prioritize the analysis of textual variations among a single play as a significant part of their constructed readers' learning experience. It is mentioned in Dawson's and Thompson's research that their reader may benefit from an introduction to textual variants, 
but only to introduce other topics: for Dawson's reader, the performance assignment, and for Thompson's reader, critical theory such as cultural materialism. The Norton, however, is the only anthology that dedicates seventeen pages to an entirely separate introduction to early modern publishing, called the General Textual Introduction, complete with four pages of facsimiles for the reader's reference. The Norton also includes three texts of King Lear: the Quarto and Folio texts, side-by-side on facing pages, and a conflation of the two. The reasoning for this, as editors Gordon McMullan and Suzanne Gossett state, is because "attention to the text itself is... an integral part of understanding the meaning of Shakespeare's works, considerably enhancing the pleasure of the reading experience" (Norton 75). Gibson stated the importance of pleasure when studying Shakespeare as well, except the student reader that he portrays finds their pleasure in the idea of Shakespeare's plays coming to life as a performance. This demonstrates how the constructed reader of the Norton and the students described by Gibson and Flachmann are dissonant in the manner in which they find pleasure when studying a Shakespearean play, which could mean that there is also dissonance in the ways in which their students might understand or appreciate Shakespeare's plays, either as a staged performance or as a text.

Another notable difference is that scholars such as Thompson and Dawson express the importance of reshaping their constructed readers' frame of thinking about Shakespeare by approaching his plays through the lens of critical theory such as feminism, cultural materialism, and new historicism while these concepts are only explicitly covered in the Riverside and Pearson, though the Norton may have implicitly been influenced by the approach. In the Riverside, the 27-page essay, "Twentieth-Century Shakespeare Criticism," devotes ten pages to Shakespeare Criticism after 1970, including critical theories such as Structuralism and 
Deconstruction (40-41); New Historicism, Cultural Materialism, Cultural Studies, and Marxism (41-44); Feminism, Gender Studies, Gay and Lesbian Criticism, and Queer Theory (44-47); and Psychoanalytic Criticism, (47-48). The Pearson dedicates thirteen pages to Shakespeare criticism, and all but two pages cover criticism in the twentieth century or later. Bevington covers critical theory such as Historical Criticism (lxxxviii-xc), "New" Criticism (xc-xci), Psychological Criticism (xci-xcii), Mythological Criticism (xcii-xciii), Typological Criticism (xciii), New Historicism and Cultural Materialism (xciv-xcv), Feminist Criticism (xcv), and Poststructuralism and Deconstruction (xcv-xcvi). This demonstrates that Thompson's constructed student may benefit the best from the Riverside and Pearson editions as an introduction to the different lenses through which one might approach a Shakespearean text. These descriptions of the different approaches, however, are absent in the Bedford, Norton, and Oxford editions.

The areas in which the readers constructed by the five anthologies overlap and diverge from the readers constructed by Shakespeare pedagogy — such as whether to emphasize the play as a performance, prioritize the textual history of the play, or approach the play through the lens of critical theory - demonstrate the various learning needs of the readers constructed by each anthology and researcher. However, the "real" readers of Shakespeare in current undergraduate classrooms are affected by the variety of tools provided in the anthologies and the teaching methods in pedagogical scholarship depending on whether the constructed readers are accurate representations of these "real" readers currently enrolled in undergraduate Shakespeare courses. These possible effects will be analyzed in the concluding section. 


\section{Conclusion}

The divergences between the imagined readers of the anthologies and the imagined readers in pedagogy research have important implications for how Shakespeare is taught and read in future undergraduate classrooms. These implications can either be beneficial or detrimental to students depending on whether pedagogy scholars' depiction of readers is accurately representative of the majority of "real" readers of Shakespeare.

Assuming the readers depicted in pedagogical scholarship are accurately representative of the "real" readers, the differences between the two constructed readers could actually be beneficial. While it may at first seem troubling that the anthologies and pedagogical scholarship are not on the same page in their approaches to the reader of Shakespeare, this variance could actually end up serving student readers who have a variety of learning needs. For example, students who learn best with performance-based activities, textual variant analysis, or critical theory have the tools to do so because there are a variety of texts and pedagogical methods that can assist them with these needs. It is not possible for there to be a single rule designated as "The Way to Teach Shakespeare" in the classroom or in the anthology because teaching Shakespeare to a multitude of students among a vast array of demographics is not a one-size-fits-all endeavor. For example, where the assigned anthology fails to assist readers with their learning and engagement with Shakespeare plays, the instructor's teaching methods can fill in the gaps, and vice versa. If a student learns best by performance activities but is assigned the Norton anthology, the student may encounter difficulties engaging with the play while doing the assigned reading, as they are instead provided with three different versions of the same play and a plethora of historical context. Their learning needs may instead be met the next day in class when their instructor leads performance activities that successfully engage the student in their 
learning. On the other hand, a different student may prefer not to participate in the in-class performance activities but may be intellectually stimulated by the historical information and images in the Norton's general introduction about the Globe Theatre in which Shakespeare's plays were first performed. These examples illustrate how divergences between the imagined readers of the anthologies and in pedagogical research may possibly be beneficial for the actual readers of Shakespeare. This suggests that instructors should consider closely how their student readers are responding to an anthology and be prepared to diverge from the anthology's approach when needed.

With this in mind, other issues arise due to the divergences among the two constructed readers, and these could be detrimental to student readers' learning in actual classrooms. Once again, if the readers depicted in pedagogical scholarship are accurately representative of "real" readers - and students do, indeed, need to be approaching Shakespeare's texts as scripts, texts in transmission, and as texts to be interpreted through critical theory—-then students' learning needs are only being partially heard by the editors and publishers of these anthologies. It would suggest that some publishers are not incorporating many of the arguments made by pedagogy scholars into their Shakespeare editions and, therefore, revisions will need to be made to the anthologies to fulfill the learning needs of their actual readers - if the publishing companies see this as a way to make profits. The Norton, for example, would need to shift more focus from textual variants to a performance-based approach; the paratexts of the Riverside, Norton, and Oxford editions would need to be revised so that the language shapes Shakespeare's characters and dramatic situations to be relevant and identifiable to twentieth century students, and nearly every edition would need to reduce the length of its general introduction to become less "demotivating" (Gibson 8) for its readers. 
Once again, these revisions would only need to take place if the reader depicted in pedagogy research is representative of a great majority of the actual readers of Shakespeare. However, due to the possible bias that comes with an instructor researching their own students (Punch 44), the notion that the reader depicted in pedagogy research is truly representative of the actual readers of Shakespeare, all from a vast array of demographics, needs to be questioned. Therefore, perhaps no revisions or only slight revisions to the anthologies are necessary. It is possible that Flachmann, for example, may have been vested in the outcome of the idea of "parallel scenes" becoming a success during the transition between new criticism and more performance-based learning. As a result, he may have interpreted the results of the intimate scene performed among students as more of a success than in reality. Or, perhaps those students who disliked the activity and found it unhelpful as a tool remained silent, leaving their instructor with an incomplete understanding of the students' true response to the classroom activity. Because neither Flachmann, Gibson, nor Dawson describe their research methodologies, it is difficult to evaluate how they accounted for their own research bias when concluding the effectiveness of their performance-based learning activities. The same might be said of the other pedagogy scholars discussed above as well. Because of the possible bias that may have influenced the researcher's results, one needs to consider that perhaps the readers depicted in Shakespeare pedagogy are not accurately representative of "real" readers of Shakespeare. In which case, problems could arise, as actual students of Shakespeare may not be receiving the tools they need to effectively learn Shakespeare. A student with certain learning needs that are not accounted for in pedagogical scholarship or in Shakespeare anthologies may find the experience of learning Shakespeare a very difficult process. An instructor may choose an anthology that closely 
resembles their teaching methods, in which case this student may not be receiving the tools they need to undergo an effective and positive learning process.

Once again, it is important to mention that the marketing staff have played a more significant role in academic publishing beginning around the time the Riverside edition (1997) was published, which means all subsequent anthologies may have been affected as well. While the anthology is marketing to cater to undergraduate readers of Shakespeare, the marketing staff is ultimately catering to the instructor who assigns the textbook in their course. Thus, it appears that the students in these courses, the "real" readers of Shakespeare unembellished by the instructor's bias or by limitations in the research subjects, still remain unheard in the academic publishing world. Even if one were to turn to the students to request their ideas about what they need to effectively learn Shakespeare, in many cases, their own answers are possibly influenced by outside factors, such as pleasing their instructors or feelings of apathy about the subject or in some cases uncertainty about what they truly need to effectively engage with Shakespeare. It seems that the best solution is to provide a variety of options, in anthologies and in the classroom, for readers to choose from that best suit their individual needs: a combination of performance-based and critical-based learning, the choice between participating in performance activities or solitary reading or a mixture of both. Having options available for readers to choose from will ultimately be the most effective way to meet the individual needs of a variety of different readers. 


\section{REFERENCES}

Bevington, David, editor. The Complete Works of Shakespeare. $7^{\text {th }}$ ed., Pearson Higher Education, 2014.

Blayney, Peter. The Texts of King Lear and Their Origins. Cambridge UP, 1982.

Boose, Lynda E. "An Approach Through Theme: Marriage and the Family." Approaches to Teaching Shakespeare's King Lear, edited by Robert H. Ray, Modern Language Association of America, 1986, pp. 59-68.

Dawson, Anthony B. "Teaching the Script." Teaching Shakespeare: Pass It On, edited by G.B. Shand, Blackwell Publishing, 2009.

Evans, G. Blakemore, and Tobin, J.M.M., editors. The Riverside Shakespeare. $2^{\text {nd }}$ ed., Houghton Mifflin Company, 1997.

Erne, Lukas. Shakespeare’s Modern Collaborators. Continuum, 2008.

Flachmann, Michael. “Teaching Shakespeare Through Parallel Scenes.” Shakespeare Quarterly, vol. 35, no. 5, 1984, pp. 644-646.

Gallagher, Catherine, and Stephen Greenblatt. Practicing New Historicism. University of Chicago Press, 2001.

Greenblatt, Stephen, editor. The Norton Shakespeare: Later Plays and Poems. $3^{\text {rd }}$ ed., W.W. Norton \& Company, Inc., 2016.

Genette, Gerard. Paratexts: Thresholds of Interpretation. Cambridge UP, 1997.

Gibson, Rex. Teaching Shakespeare: A Handbook for Teachers. $2^{\text {nd }}$ ed., Cambridge University Press, 2016.

Hunter, Michael. Editing Early Modern Texts: An Introduction to Principles and Practice. Palgrave Macmillan, 2006.

Iser, Wolfgang. The Act of Reading: A Theory of Aesthetic Response. Johns Hopkins UP, 1978.

Jowett, John. "Emendation and Modernization." Shakespeare and Text. Oxford UP, 2007.

Kelemen, Erick. Textual Editing and Criticism. W.W. Norton \& Company, 2009.

Kidnie, Margaret Jane. "Text, Performance, and the Editors: Staging Shakespeare's Drama." Shakespeare Quarterly, vol. 51, no. 4, 2000, pp. 456-473.

McDonald, Russ, and Orlin, Lena Cowen, editors. The Bedford Shakespeare. $1^{\text {st }}$ ed., Bedford/St. Martin's, 2015.

Parker, Robert Dale. How to Interpret Literature. Oxford UP, 2008. 
Punch, Keith F and Alis Oancea. Introduction to Research Methods in Education. SAGE Publications Inc., 2014.

Tanselle, G. Thomas. “The Editing of Historical Documents.” Studies in Bibliography, vol. 31, 1978, pp. 1-56.

Taylor, Gary, and Jowett, John, editors. The New Oxford Shakespeare: The Complete Works. Modern Critical ed., Oxford UP, 2016.

Thompson, Ann. "King Lear and the Politics of Teaching Shakespeare." Shakespeare Quarterly, vol. 41, no. 2, 1990, pp. 139-146.

Thompson, John B. Books in the Digital Age: The Transformation of Academic and Higher Education Publishing in Britain and the United States. John Wiley \& Sons, 2013.

Walker, Alice. "Principles of Annotation: Some Suggestions for Editors of Shakespeare." Studies in Bibliography, vol. 9, 1957, pp. 95-105.

Warren, Michael. "Teaching with a Proper Text.” Approaches to Teaching Shakespeare's King Lear, edited by Robert H. Ray, Modern Language Association of America, 1986, pp. 105-110. 